\title{
The Study of Corrosion Stability of Organic Epoxy Protective Coatings on Aluminium and Modified Aluminium Surfaces
}

\author{
Zorica Ž. Lazarevic $c^{*}, a$, Vesna B. Mišković-Stanković ${ }^{a}$, Zorica Kačarević-Popovićc ${ }^{b}$ and \\ Dragutin M. Dră̌ićc \\ ${ }^{a}$ Faculty of Technology and Metallurgy, University of Belgrade, P.O. Box 3503, 11120 Belgrade, \\ Serbia and Montenegro \\ ${ }^{b}$ Institute of Nuclear Science "Vinča”, P.O.BOX 522, 11001 Belgrade, Serbia and Montenegro \\ ${ }^{c}$ ICTM-IEC, P.O. Box 815, 11000 Belgrade, Serbia and Montenegro
}

\begin{abstract}
Revestimentos de epóxido foram obtidos através da eletrodeposição catódica de uma resina epóxi sobre alumínio e superfícies de alumínio modificadas (fosfatadas, cromadas-fosfatadas e anodizadas) usando o método potenciostático (concentração da resina de $10 \%$ em massa, temperatura de $27{ }^{\circ} \mathrm{C}$ e tensão de $250 \mathrm{~V}$ ). A corrosão desses revestimentos foi investigada durante exposição ao $\mathrm{NaCl}$ 3\% usando espectroscopia de impedância eletroquímica (EIS) e medidas de polarização. A partir da medida da dependência da resistência, da capacitância e da permissividade, obtida da EIS, e da velocidade da reação de desprendimento de hidrogênio no banho de eletrodeposição, obtida das curvas de polarização, pode-se observar que o revestimento epóxido sobre o alumínio e superfícies de alumínio modificadas constitui uma boa barreira ao transporte de agentes corrosivos. O tempo de contato entre o eletrólito e a superfície do alumínio sob o revestimento é muito maior no caso das superfícies modificadas por cromagem-fosfatização e anodização.
\end{abstract}

Epoxy coatings were formed by cathodic electrodeposition of an epoxy resin on aluminium and modified aluminium surfaces (phosphatized, chromatized-phosphatized and anodized aluminium) using a constant voltage method (resin concentration $10 \mathrm{wt} . \%$, temperature $27^{\circ} \mathrm{C}$, applied voltage $250 \mathrm{~V}$ ). The corrosion behavior of these coatings was investigated during exposure to $3 \% \mathrm{NaCl}$ using electrochemical impedance spectroscopy (EIS) and polarization measurements. From the dependence of resistance, capacitance and relative permittivity of the coating, obtained from EIS, on the rate of hydrogen evolution reaction in the electrodeposition bath, obtained from polarization curves, it can be observed that the epoxy coating on aluminium and modified aluminium surfaces is a good barrier against the transport of corrosive agents. The time corresponding to contact between electrolyte and aluminium surface under the coating is greater in the case of surface modification by chromato-phosphatized and anodized aluminium than in the case of phosphatize one.

Keywords: aluminium, corrosion, electrodeposition, epoxy coatings, EIS

\section{Introduction}

The ability of an organic coating to protect a metal substrate against corrosion generally depends on: ${ }^{1-4}$ (a) the quality of the coating, i.e., its chemical and mechanical properties, adhesion to the substrate, water uptake and permeability to water, oxygen and ions; (b) the characteristics of the substrate and the surface modification; (c) the properties of the metal/coating interface. It is well known that surface pretreatment

* e-mail: Lzorica@softhome.net employed for a metallic substrate can have a large effect on the lifetime of a metal/coating system. Protective organic coatings formed during cathodic electrodeposition have been recently introduced in car industry and substitute steel, partially or even absolutely the steel due to its high strength/stiffness to weight ratio and good corrosion resistence. $^{5}$

The electrodeposition of water-dispersed organic coatings is a complex electrochemical process ${ }^{6}$ which includes, as the first step, hydrogen evolution by water discharge on a cathode:

$2 \mathrm{H}_{2} \mathrm{O}+2 \mathrm{e}^{-} \rightarrow \mathrm{H}_{2}+2 \mathrm{OH}^{-}$ 
followed by electrocoagulation of resin micelles at the cathode surface by neutralization of positively charged groups in the resin with electrochemically generated $\mathrm{OH}^{-}$ions:

$\mathrm{R}-\mathrm{NH}_{3}^{+}+\mathrm{OH}^{-} \rightarrow \mathrm{R}-\mathrm{NH}_{2}+\mathrm{H}_{2} \mathrm{O}$

The aim of this work was to investigate the electrochemical properties of epoxy coatings on aluminium and modified aluminium surfaces (anodized aluminium, phosphatized and chromatized-phosphatized aluminium) and to explain the effect of surface modification on the protective properties of epoxy coatings electrodeposited on aluminium and modified aluminium. Thin, non-pigmented epoxy coating (primer) without top coat was electrodeposited in order to investigate the effect of metal surfaces and surface modification more accurately.

\section{Experimental}

The test aluminium panels ( $\mathrm{Al} 99.5 \%$, dimension 20 $\mathrm{mm} \times 20 \mathrm{~mm}$ x $0.23 \mathrm{~mm}$ ) were pre-treated by degreasing in $10 \mathrm{~g} \mathrm{dm}^{-3}\left(\mathrm{NaOH}+\mathrm{Na}_{3} \mathrm{PO}_{4} \cdot 10 \mathrm{H}_{2} \mathrm{O}+\mathrm{Na}_{2} \mathrm{CO}_{3}\right)$, at $50{ }^{\circ} \mathrm{C}$, for $3 \mathrm{~min}$; pickling with a $5 \% \mathrm{NaOH}$, at $50{ }^{\circ} \mathrm{C}$, for $3 \mathrm{~min}$; brightening with $12 \% \mathrm{HNO}_{3}$, at room temp., for $0.5 \mathrm{~min}$ and rinsing with distilled water. The previously pretreated aluminium were electrochemically anodized in $20 \% \mathrm{H}_{2} \mathrm{SO}_{4}$ ( $j=1.8 \mathrm{~A} \mathrm{dm}^{-2}, \tau=12.5 \mathrm{~min}, \delta=5 \mu \mathrm{m}$, room temp.). ${ }^{7,8}$ Anodized aluminium was hot water siling $(\tau=6.5 \mathrm{~min}$, at $\left.100{ }^{\circ} \mathrm{C}\right)$. The previously pretreated aluminium was chemically phosphatized (5\% "Alfos", based on Naphosphates; at $50{ }^{\circ} \mathrm{C}$, for $\left.3 \mathrm{~min}, \delta=0.5-1 \mu \mathrm{m}, \mathrm{pH} 4.7\right)$ and chromatized-phosphatized in solution $\left(58 \mathrm{~g} \mathrm{dm}^{-3} \mathrm{H}_{3} \mathrm{PO}_{4}\right.$, $7 \mathrm{~g} \mathrm{dm}^{-3} \mathrm{CrO}_{3}, 4.5 \mathrm{~g} \mathrm{dm}^{-3} \mathrm{NaF}$; at room temp., for $2 \mathrm{~min}$, $\delta=0.5-1 \mu \mathrm{m}, \mathrm{pH} 1.85)$.

Protective epoxy coatings were formed during cathodic electrodeposition of an epoxy resin modified by amine and isocyanate on aluminium and previously modified aluminium using constant voltage method (resin concentracion $10 \mathrm{wt} . \%$, temperature $27^{\circ} \mathrm{C}$, applied voltage $250 \mathrm{~V}) .{ }^{9}$ After coating for $3 \mathrm{~min}$, rinsing and curing at $180{ }^{\circ} \mathrm{C}$ for $30 \mathrm{~min}$, the film thickness, was $20 \mu \mathrm{m}$.

In order to evaluate the electrochemical properties of the epoxy coating, electrochemical impedance spectroscopy (EIS) measurements were performed. The coated samples were exposed to $3 \% \mathrm{NaCl}$ in destilled water for periods of 100 days. A three-electrode cell arrangement was used in the experiments. The working electrode was a coated aluminium or modified aluminium panel fixed in a special Teflon holder. The counter electrode was a platinum mesh with a surface area considerably greater than that of the working electrode. The reference electrode was a saturated calomel electrode (SCE). The AC impedance data were obtained at the open-circuit potential using a PAR 273 potentiostat and a PAR 5301 lock-in amplifier. The impedance measurements were carried out over a frequency range of $100 \mathrm{kHz}$ to $5 \mathrm{mHz}$ using a $5 \mathrm{mV}$ amplitude sinusoidal voltage. The impedance spectra were analyzed using a suitable fitting procedure.

The rate of the hydrogen evolution reaction in the polymer solution on aluminium and modified aluminium surfaces was determined with a rotating disc electrode using a slow sweep voltammetry (rotation of $2000 \mathrm{rpm}$, sweep rate $1.0 \mathrm{mV} \mathrm{s}^{-1}$ ). The counter electrode was a Pt spiral wire and the reference electrode was a SCE.

\section{Results and Discussion}

Organic polymer coatings, formed on metallic substrate, show ideal behavior as dielectrics. After exposition to a corrosive agent, organic coatings behave in a different maner due to the appearance of electrolyte activated raching conductive areas, so called "tracks", which pass through the coatings metal, where electrochemical reactions take place. This interpretation of behavior organic coatings on steel and aluminum alloys and effect of corrosion agent is found by numerous authors. ${ }^{10-14}$ An equivalent electrical circuit model for the behavior of polymer-coated metal in corrosive environments has been used (Figure 1), where $R_{\Omega}$ is the resistance of the electrolyte, $R_{\mathrm{p}}$ is the coating pore resistance due to electrolyte penetration, $C_{\mathrm{c}}$ is the coating capacitance, $R_{\mathrm{ct}}$ is the charge-transfer resistance, $Z_{\mathrm{w}}$ is the Warburg impedance. By fitting the experimental data, from the impedance plots in the complex plane, ${ }^{15}$ the pore resistance, $R_{\mathrm{p}}$, coating capacitance, $C_{\mathrm{c}}$, charge-transfer resistance, $R_{\mathrm{ct}}$ and double-layer capacitance, $C_{\mathrm{d}}$ were determined and plotted as function of time in Figures 2, 3, 4 and 5, respectively.

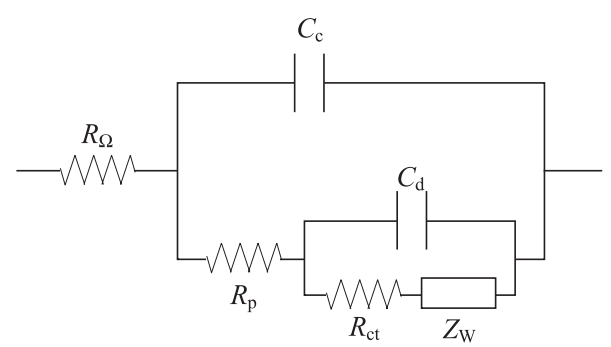

Figure 1. Equivalent electrical circuit of a polymer-coated metal.

Figures 2 and 3 show the time dependences of pore resistance, $R_{\mathrm{p}}$ and coating capacitance, $C_{\mathrm{c}}$, during exposure to a corrosive agent $(3 \% \mathrm{NaCl})$. It can be seen that the pore resistance decreases and coating capacitance increases for the first few days, denoting the entry of electrolyte into the epoxy coating. ${ }^{16,17}$ This is the first step of electrolyte 
penetration through an organic coating and it is related to water uptake, when molecules of pure water diffuse into the micropores of the polymer net according to Fick's law. ${ }^{18}$ After that initial period, the values of pore resistance and coating capacitance reach a plateau and remain almost unchanged over a long time period, indicating the maintenance of good protective properties due to the existence of the passive oxide film (anodic, chromatophosphate and phosphate layer). This is the second step of electrolyte penetration and it refers to the penetration of water and ions through the macropores of the coating which become deeper with time, until they finally pass through the epoxy coating and reach the metal surface. This leads to the beginning of electrochemical processes on the metallic interface and, as a consequence, to the loss of coating adhesion. The significantly higher values of $R_{\mathrm{p}}$

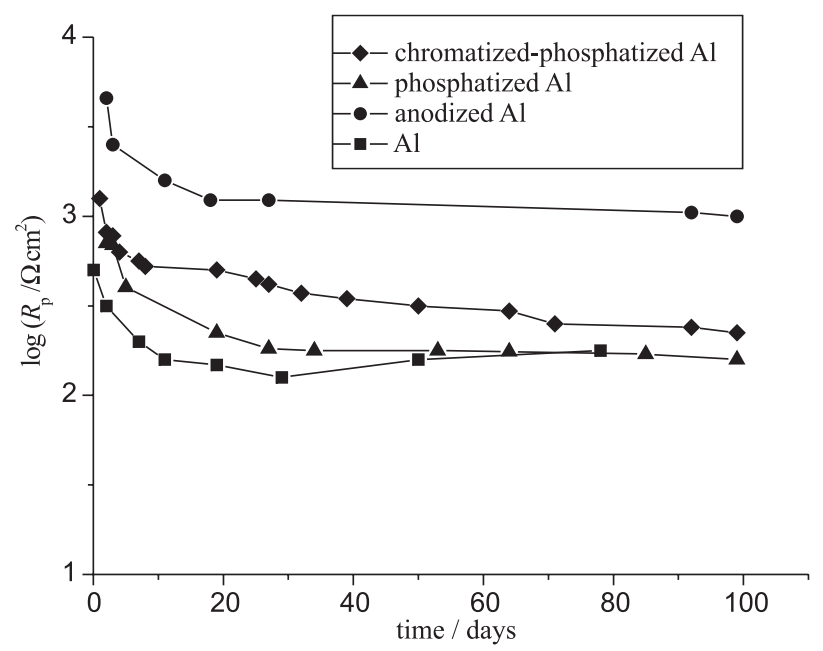

Figure 2. The time dependence of pore resistance for epoxy coatings electrodeposited on aluminium and modified aluminium surfaces, during exposure to $3 \% \mathrm{NaCl}$.

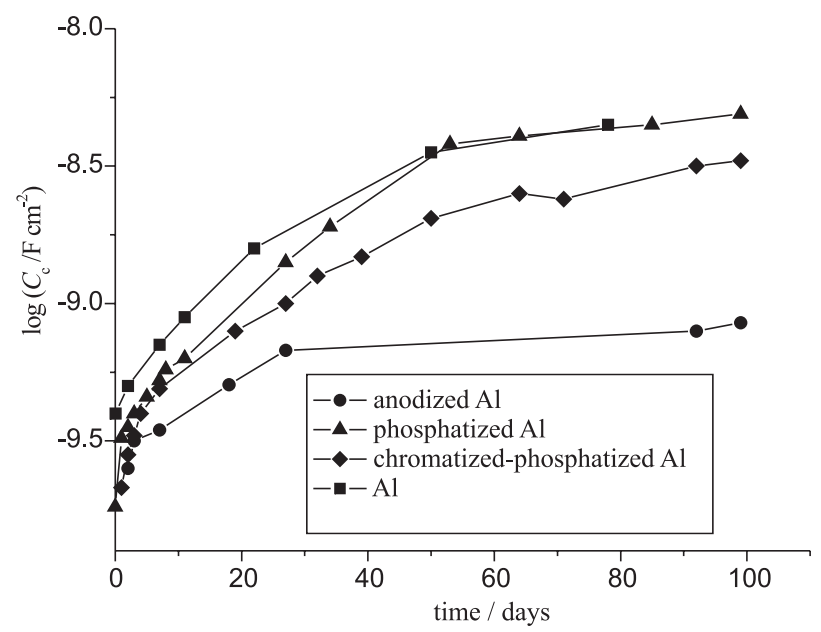

Figure 3. The time dependence of coating capacitance for epoxy coatings electrodeposited on aluminium and modified aluminium surfaces, during exposure to $3 \% \mathrm{NaCl}$. and lower values of $C_{\mathrm{c}}$ for the epoxy coatings on anodized and chromatized-phosphatized aluminium than the same coatings on phosphatized aluminium and aluminium indicate the greater corrosive stability. However, low values of $R_{\mathrm{p}}$ for all epoxy coatings can be explained by the fact that these coatings are thin non-pigmented primers without top coats and they are not complete protective systems.

The charge-transfer resistance, $R_{\mathrm{ct}}$ and double-layer capacitance, $C_{\mathrm{d}}$, are plotted as a function of time (Figures 4 and 5, respectively). Initially, for all coatings, the chargetransfer resistance decreases, while double-layer capacitance increases. After that initial period, the doublelayer capacitance and charge-transfer resistance have unchanged values during long exposure time. This behavior confirmed hypothesis of the existence of passive film on the aluminium surface, which prevents corrosion

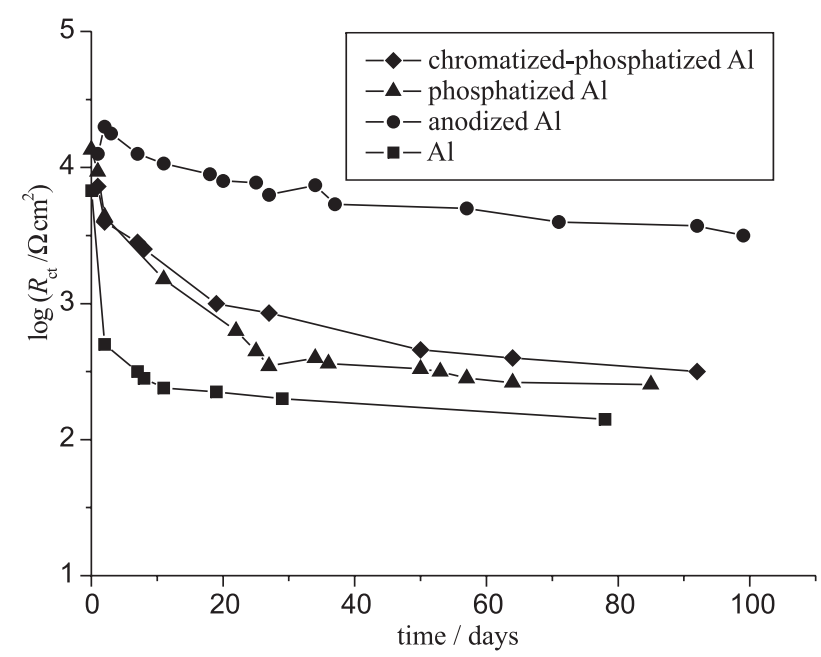

Figure 4. The time dependence of charge-transfer resistance for epoxy coatings electrodeposited on aluminium and modified aluminium surfaces, during exposure to $3 \% \mathrm{NaCl}$.

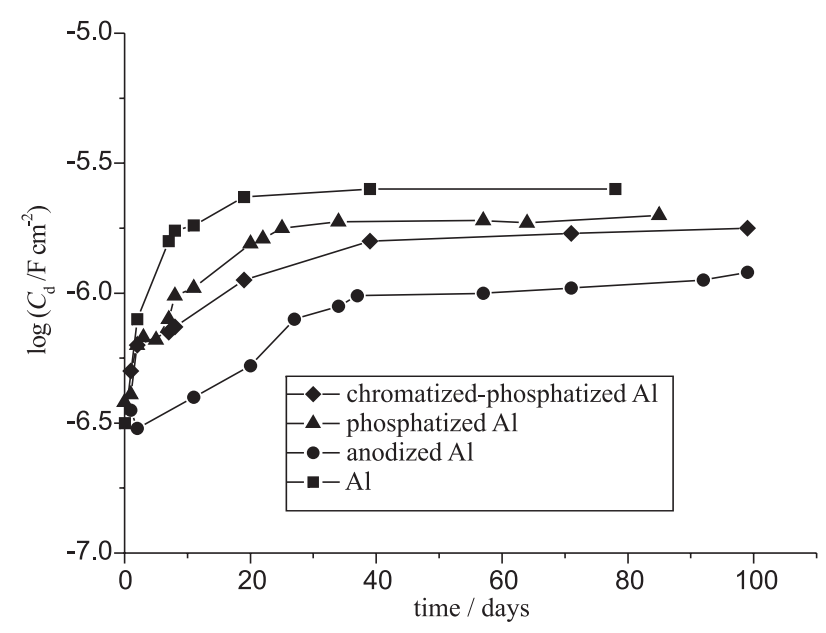

Figure 5. The time dependence of double-layer capacitance for epoxy coatings electrodeposited on aluminium and modified aluminium surfaces, during exposure to $3 \% \mathrm{NaCl}$. 
process at the substrate. The lower values of $C_{\mathrm{d}}$ and higher values of $R_{\mathrm{ct}}$ for the same epoxy coatings on anodized and chromatized-phosphatized aluminium than on phosphatized aluminium and aluminium indicate also that epoxy coatings on anodized and chromatizedphosphatized aluminium have greater corrosion stability due to existence of the passive anodic oxide and chromatophosphate layer.

The relative permittivity of epoxy coating, $\varepsilon_{\mathrm{r}}$, was calculated from film thickness, $\delta$ and coating capacitance, $C_{c}$, using the equation:

$\varepsilon_{\mathrm{r}}=C_{\mathrm{c}} \delta / \varepsilon_{\mathrm{o}}$

where $\varepsilon_{\mathrm{o}}=8.85 \times 10^{-12} \mathrm{~F} \mathrm{~m}^{-1}$ is the permittivity of the vacuum. The time dependence of relative permittivity is presented in Figure 6. The values of relative permittivity around 10 in saturation indicate the low water content in the epoxy coating on anodized aluminium and its lower porosity and better corrosion stability comparing with coatings on other substrates.

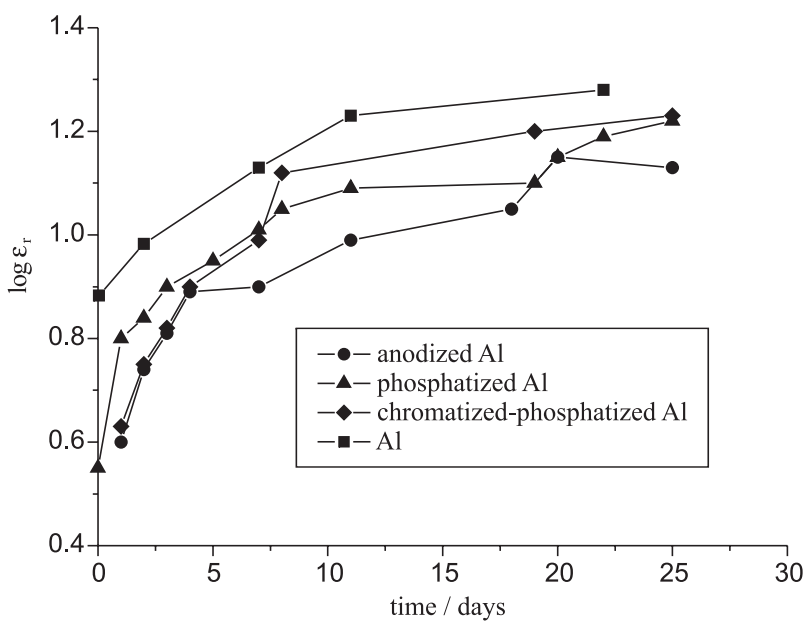

Figure 6. The time dependence of relative permittivity for epoxy coatings electrodeposited on aluminium and modified aluminium surfaces, during exposure to $3 \% \mathrm{NaCl}$.

The differences in electrochemical properties can be explained by different rates of hydrogen evolution during epoxy coating deposition on different substrates (Figure 7) and different wettability. ${ }^{19-21}$ Faster hydrogen evolution (Figure 7) and lower wettability on phosphatized aluminium and aluminium than on anodized and chromatized-phosphatized aluminium causes the accumulation of hydrogen on the cathode during subsequent electrodeposition of the epoxy coating. During further curing for epoxy coating formation, hydrogen evolves, leaving more vacancies in the polymer matrix and causing a more porous structure of the epoxy coating on phosphatized aluminium and aluminium in regard to epoxy coating on anodized and chromatizedphosphatized aluminium. This explains the lower protective properties of these coatings: smaller values of $R_{\mathrm{p}}$ and $R_{\mathrm{ct}}$ and higher values of $C_{\mathrm{c}}, \varepsilon_{\mathrm{r}}$ and $C_{\mathrm{d}}$ (from EIS).

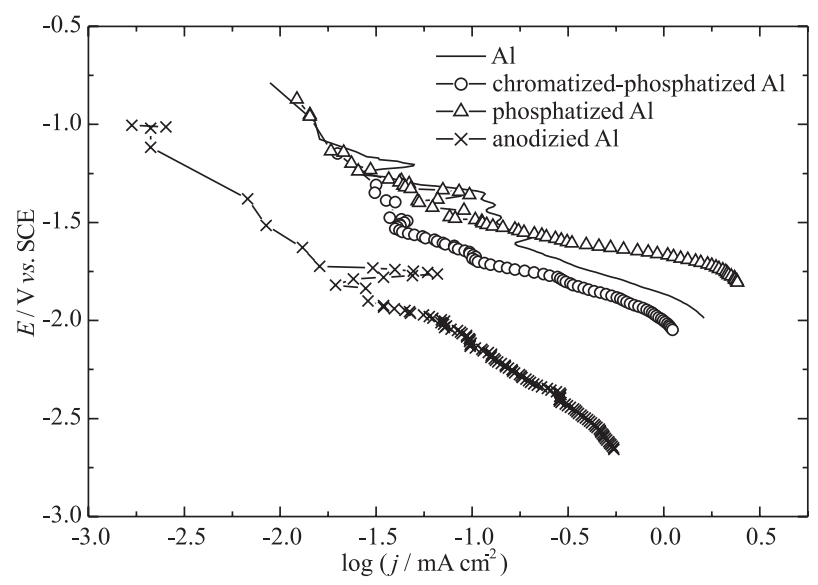

Figure 7. Polarization curves for hydrogen evolution on aluminium and modified aluminium surfaces in polymer solution at $25{ }^{\circ} \mathrm{C} ; \mathrm{N}_{2}$ saturated; $\omega=2000 \mathrm{rpm} ; n=1.0 \mathrm{mV} \mathrm{s}^{-1}$.

\section{Conclusions}

Epoxy coatings were formed during the cathodic electrodeposition of an epoxy resin on aluminium and previously modified aluminium using the constant voltage method. From the experimental results obtained from electrochemical impedance spectroscopy (pore resistance, coating capacitance, charge-transfer resistance, doublelayer capacitance, relative permittivity of the coating), it can be concluded that the protective properties of the epoxy coatings on anodized and on chromatizedphosphatized aluminium are significantly improved with respect to the same epoxy coatings on aluminium and on phosphatized aluminium: higher values of pore resistance and charge-transfer resistance, and lower values of coating capacitance, double-layer capacitance and relative permittivity of the coating (from EIS). This behavior can be explained by the lower porosity of the epoxy coatings on anodized and on chromatized-phosphatized aluminium, resulting from the lower rate of $\mathrm{H}_{2}$ evolution and the better wettability.

\section{References}

1. Deflorian, F.; Fedrizzi, L.; Bonora, P. L.; Corrosion 1994, 50, 113.

2. Rammelt, U.; Reinhard, G.; Prog. Org. Coat. 1992, 21, 205. 
3. Westing, E. P. M.; Ferrari, G. M.; Wit, J. H. W.; Corros. Sci. 1994, 36, 957.

4. Stratmann, M.; Feser. R.; Leng, A.; Electrochim. Acta 1994, 39, 1207.

5. Machu, W.; Handbook of Electropainting Technology, Electrochemical Publications Ltd.: London, 1978, p. 3.

6. Beck, F. In Comprehensive Treatise of Electrochemistry; Bockris, J. O’M.; Conway, B. E.; Yeager, E.; White, R. E., eds.; Plenum Press: New York, 1981, vol.2, p. 537.

7. Hoar, T. P.; Yahalom, J.; J. Electrochem. Soc. 1963, 110, 614.

8. Keller, F.; Hunter, M. S.; Robonson, D. L.; J. Electrochem. Soc.1953, 100, 411.

9. Mišković-Stanković, V. B.; Stanić, M. R.; Dražić, D.M.; Prog. Org. Coat. 1999, 36, 53.

10. Touhsaent, R. E.; Leidheiser Jr, H.; Corrosion 1972, 28, 435.

11. Kendig, M. W.; Leidheiser Jr, H.; J. Electrochem. Soc. 1976, 123, 982.

12. Mansfeld, F.; Corrosion 1981, 37, 301.

13. Mansfeld, F.; Kendig, M. W.; Tsai, S.; Corrosion 1982, 38, 478.

14. Kendig, M. W.; Mansfeld, F.; Tsai, S.; Corros. Sci. 1983, 23 , 317.
15. Boukamp, B.; Sol. St. Ionics 1986, 20, 31.

16. Mišković-Stanković, V. B.; Dražić, D. M.; Teodorović, M. J.; Corros. Sci. 1995, 37, 241.

17. Mišković-Stanković, V. B.; Dražić, D. M.; Kačarević-Popović, Z.; Corros. Sci. 1996, 38, 1513.

18. Mišković-Stanković, V. B.; Zotović, J. B.; Kačarević-Popović, Z.; Maksimović, M D.; Electrochim. Acta 1999, 44, 4269.

19. Mišković-Stanković, V. B.; Lazarević, Z. Ž.; KačarevićPopović, Z. M.; J. Serb. Chem. Soc. 2001, 66, 871 (www.shd.org.yu/HtDocs/SHD/Vol66/No11-12.htm, accessed in June 2001).

20. Mišković-Stanković, V. B.; Lazarević, Z. Ž.; KačarevićPopović, Z.; Dražić, D. M.; Bull. Electrochem. 2002, 18, 343.

21. Lazarević, Z. Ž.; Mišković-Stanković, V. B.; Dražić, D. M.; Kačarević-Popović, Z.; Book of Abstracts of 54th Annual Meeting of the International Society of Electrochemistry, Sao Pedro, State of Sao Paulo, Brazil, 2003, p. 145.

Received: September 19, 2003 Published on the web: January 25, 2005 